\title{
Leaders and Universities - Revelations of Charismatic Presidents
}

\author{
Ayibuen·Bieerlike \\ Kaikeba Technology Co., LTD, No. 8 Dongbeiwang Road, Haidian District, Beijing, China \\ 739760474@qq.com
}

\begin{abstract}
Contemporary China is the China of reform, and without reform, the development and prosperity of well-established institutions, politics, and culture will be impossible. Universities, as critical institutions that teach, educate, and lead society, require continuous reform in the face of fierce international competition and the relentless push of multicultural waves. In retrospect, a university's success is inextricably linked to its "famous teachers" and "famous presidents." While the direction of development varies by university and the reforms implemented by university presidents vary as well, there are some commonalities in presidents' leadership models that can be learned. The purpose of this paper is to examine the similarities between the charismatic figures represented by Cai Yuanpei and the significant role they played in the reform and development of universities, in order to provide useful inspiration for the reform of contemporary university presidents.
\end{abstract}

Keywords: Cai Yuanpei, Peking University, Reform, Charisma theory, Revelation.

\section{Why History Chose Cai Yuanpei}

When universities first emerged in the Middle Ages, there was the famous teacher Abélard, who was considered "one of the most outstanding pioneers among the liberators of human thought," and the University of Paris, under Abélard's influence, became one of the most famous universities in the Middle Ages; Humboldt's reforms at the University of Berlin elevated the German university to the status of a first-class university, and the University of Berlin became known as the University of Berlin. This demonstrates that while the success or failure of a university cannot be separated from the time period's specific social environment and various effective institutional structures, the role of leaders should not be overlooked.

Before Cai Yuanpei became president of Peking University, the university was a "mirror" of the Republican society, and the campus smelled of feudalism and backwardness. It seemed that there was no bright future in sight here, and the so-called university had long since ceased to be a place for the "study of profound learning," so how could such a university lead society?

After taking office, Cai Yuanpei proposed a series of reforms, including the idea of "inclusiveness and academic freedom" and some advanced democratic management concepts, which seemed to be out of step with the society at that time, and even some old-fashioned people who opposed the reforms also hindered the development of the reforms.

Under all these unfavorable conditions, Cai Yuanpei broke through the resistance and took "academic development of the country" as the basic starting point, and conveyed the view of "academic research first" to every person in Peking University, which became a new university under the concept of "inclusiveness and academic freedom".

But when we think about it, why did Cai Yuanpei bring such a significant change to Peking University, and why was this person Cai Yuanpei? In addition to the systematic construction of the system, the scientific management style and other initiatives in line with the historical trend, is there another reason, although history does not allow assumptions, but imagine if the implementation of this reform is replaced by others, whether the same success? In the author's opinion, Cai Yuanpei himself can be credited with this reform.

Cai Yuanpei was not a so-called "saint" who transcended history, but a person who was good at following the trend of the times. Before he went abroad, Cai Yuanpei belonged to the popular school of comparison at that time, the so-called comparison, that is, he thought that the culture and system of the West at that time could be already in the traditional Chinese culture. Later, during his study and life in Germany, he slowly changed his views and advocated absorption, digestion and intermingling. Cai Yuanpei took a very clever approach when introducing the German model. On the one hand, he studied the German model and introduced many advanced European views at that time, which was welcomed by the Europeanized faction on campus. On the other hand, he did not advocate total westernization, and was good at using the mutual evidence of traditional Chinese culture and European culture, which was rightfully recognized by the old guard, which was the overwhelming point of Cai Yuanpei's reform.

This is one of the most important reasons why the presidents of some universities today are so determined to reform, and although they are on the right track, they bring great resistance. The academic transformation and reform of the academic system that Cai Yuanpei brought to Peking University led to its rapid development and the cultivation of talents that made important contributions to the rise of China. As a result, he is referred to as the "Father of Peking University."

While we recognize that a university's success is inextricably linked to the establishment of various institutions, the adherence to various principles, and the university's philosophy, the president of the university or the opinion leader plays a critical role in the university's development. Their unique charisma is consistent with what Max Weber referred to as charisma characteristics. 


\section{Charisma and Cai Yuanpei}

Weber originally mentioned charisma characters in his book Economy and Society, and he divided the types of authority, also called types of rule, into three types, one is the traditional type of rule, such as patriarchs, tribal chiefs and the like also belong to this type, their belief is: "Obey me, for you my people." The second type is the juridical type of rule, such as rulers who are elected. They will say, "Obey me, for I am the legal leader." The last type is the charismatic type of rule, those who have outstanding personalities, such as prophets, saints and revolutionary leaders, who believe, "Obey me, for I can make a difference in your life."

Originally a religious term meaning "divine gift" and derived from Christianity, the term charisma initially referred to an extraordinary person who was helped by God, but Weber later retained its religious connotation and extended it to a leader with extraordinary charisma and power. Such leaders are usually surrounded by a large number of people, who form a charismatic organization. This type of organization has the following characteristics: (1) It always appears in times of political, economic, and cultural crises, such as the large number of followers around Gandhi, which is the charismatic organization that appears in India when the country is facing a decision. (2) When the leader of this organization leads the collective, it is not a leadership model formed solely by his own professional knowledge, but an authority based on personal charm and character. The people in the organization obey the authority not out of rational choice, but based on the worship of leaders. Mao Zedong is not a good general, but when the revolution is faced with many crises, there will still be many followers, which also has the characteristics of charisma. (3) Strongly revolutionary, the charisma organization was eager to break with the old and establish the new. (4) The revolutions produced by charisma organizations are led by spiritual revolutions. The former Cuban leader Che Guevara, who still has a large following today, is a reflection of this characteristic.

Weber's charisma theory, with its emphasis on the concepts of faith and spirit, sees the role played by leaders in a reform as pivotal, even epoch-making. Take the reform of Peking University President Cai Yuanpei as an example, the reason why the reform of Peking University can still go forward under heavy resistance is inseparable from the historical background and necessary institutional system at that time, but it is inseparable from the personal charisma of Cai Yuanpei himself. This is evident from the comments made by many people who followed Mr. Cai, such as Lin Yutang, who said, "There is no second Mr. Cai in the world." It can be seen that he admired and admired Cai Yuanpei. Similarly, Feng Youlan also said that the reason why Cai Yuanpei was loved by his students was entirely the inspiration of his personality. It can be seen that Cai Yuanpei was not only admired by his teachers but also deeply admired by his students. Cai Yuanpei himself was a kind of charismatic character. First of all, as mentioned above, the charisma of the charismatic had extraordinary charisma, and their charisma would bring a group of followers, which in turn formed a charisma organization, and the revolutionary nature of the organization paved the way for reform and cleared many obstacles. When Cai Yuanpei was young, he traveled to Europe and studied in
Germany, fully learning the characteristics of Humboldt University in Berlin. Many of the ideas in the reform of Peking University were also directly felt by Cai Yuanpei during his study life in Germany. During the Republic of China, his experience as Minister of Education was also the reason why he became familiar with people of various schools of thought very early, whether they were new school figures such as Chen Duxiu or representatives of the old school such as Liu Shipei. The familiarity with both the old and the new factions laid the mass foundation for the future reform. Mr. Cai Yuanpei himself was very rich in experience and knowledge, and he often made people look up to him. His high academic status and charismatic personality were key factors in Cai Yuanpei's success in reforming Peking University, and these factors were also important accumulations that helped Cai Yuanpei become a charisma figure.

\section{Inspiration of Charisma to Contemporary University Presidents}

The first-class universities and principles of the world is a major strategic decision for the development of higher education in China, which puts higher demands on universities. Under the background of popularization of higher education, universities are facing new situations and challenges. In order to adapt to the trend of the times, university presidents should strive to be leaders. The reform of contemporary universities is imperative, and the appearance of charismatic figures is also needed. Then, how can the president, the general of university reform, play the charisma effect, improve his leadership and be the "helmsman" in the reform?

University reform is a war of new culture against old culture, therefore, charismatic figures will play a crucial role in this war. The famous university presidents in history have become famous along with the famous universities. The reason why the name of the university president is famous is not the number of awards he has won outside the university, but the fact that during his tenure, he has reformed the university into a place for the study of high learning, so that the university leads the society, and they make the university more famous, while becoming famous themselves for ages.

\subsection{Combination of East and West, Profound Knowledge}

As the president of a contemporary university, he or she must be at the forefront of reform and understand the direction of university development in the world today, not only in terms of academic achievements, but also as a "connoisseur". At the same time, he or she must understand Chinese and Western cultures and the development models of top universities, and must respect the local culture, conform to the development characteristics of Chinese universities, take the essence of them, learn from advanced schools, and maintain the spiritual essence of his or her own university. A contemporary president who is well-educated in both Chinese and Western cultures and has a great deal of knowledge will have a special charisma and a large number of followers. While the Chinese and Western cultures are exchanging and colliding in such a president, it will also reflect the inherent humanistic qualities and scientific spirit of a president. This spirit will help him or 
her to lay a deep foundation for reform and to develop a stronger belief in reform. Therefore, the success of charismatic people is often the inevitable choice of history

\subsection{Firm Beliefs, Breaking Through Prejudices}

Faith plays an important role. Only those who have firm ideals and beliefs can break the old pattern and prejudice in the reform, which is also a necessary psychological quality for charismatic characters. The reform is not smooth sailing, and there will be various frustrations and failures. Some people may choose to give up and find another way. But characters with charismatic temperament, when they encounter difficulties and failures, although they will also experience some low points, but they are useful to come out from failure with great strength, learn from the experience of failure and quickly come out from failure, which is the ability they have to go to success. Firm conviction is the most powerful booster that allows him to break all obstacles. What a principal needs to do when facing the bottleneck of reform is to rely on this conviction, to keep breaking through, not to give up lightly, and to make decisive choices. A character with this temperament forms around him the loyalty of the charisma organization to be stronger than the general organization, and the leader does not face difficulties when panic and finally make the right judgment, will deepen the charisma organization's identification with authority and make it easier to effectively implement strategies in reform.

\subsection{Realizing Ideals Based on the Present}

The university's ideal is inextricably linked to the university's direction and mode of development, and is the bedrock of the university's success. As a charismatic president, he or she should be an outspoken advocate and practitioner of the university's ideals. On the one hand, it demonstrates the president's understanding of education, while also demonstrating that he has a clear vision and direction for the future development of Mao Zedong believed that "a star's fire can ignite a prairie fire." The same is true for a leader's observation of events; his grasp of the phenomenon's essence is one of the necessary abilities for becoming a charismatic president. Mei Yiqi, the president of Tsinghua University, proposed a policy of running the university in light of the social reality of the time, "In a nutshell, it can be said to cultivate talents for social construction," which demonstrated a clear understanding of the university's development trend under the historical circumstances of the time, and thus promoted the construction and development of Tsinghua University, as well as establishing his position in the university's reform. He also established his position during Tsinghua University's reform. To be a charismatic president, having a vision, not being fixated on the immediate future, having a long-term perspective, and the ability to implement pragmatic reforms are all necessary characteristics.

\subsection{Education for the Nation and Patriotism}

In leading a university, the president must have a thorough understanding of the university spirit and the type of university spirit that should be promoted during a given era. A strong university spirit can guide the university's development, and the talents nurtured are also the living embodiments of these spirits, which will continue to exist. On the other hand, a university devoid of spirit is comparable to a tree devoid of water, which remains barely alive but eventually deteriorates into a withered branch. While the university's values are universal, the university's president should have a distinct national sentiment. Because the university's national character is ingrained in its spirit. Thus, in the new era, promoting patriotism and establishing a university with Chinese characteristics is the goal of our contemporary Chinese universities, and in shaping this spirit, the unique temperament possessed by charismatic presidents is critical to success.

At present, our universities are in a new era of peace and stability, and the historical environment of university presidents is also very different from that of the Republic of China, when there were many disturbances, wars and warlords, but the educational sentiments of many famous charismatic presidents in that stormy period of the Republic of China are still the examples we need to learn in this era, that is, to make our country truly from a big country to a strong one through education to a strong nation.

\section{References}

[1] Chen Hongjie. The German classical view of university and its influence on China [M]. Beijing: Peking University Press, 2002.

[2] Wang J, Zhu Shiming. The academic canon. A Study of the Beginnings of Modern Chinese Higher Education [M]. Tianjin: Tianjin University Press, 2010.

[3] Max Weber. Weber on the University [M]. Nanjing: Jiangsu People's Publishing House, 2006.

[4] Zhang Weiying, The Logic of the University [M] Beijing: Peking University Press, 2006.

[5] Liu Chao, Li Yue. Mei Yiqi and the Rise of Tsinghua [[J]. Journal of Tsinghua University, 2012 